\title{
Location of Pharyngeal Residue Following Swallowing
}

National Cancer Institute

\section{Source}

National Cancer Institute. Location of Pharyngeal Residue Following Swallowing. NCI

Thesaurus. Code C127336.

An observation of the location of pharyng eal residue remaining after an individual swallows. 